\title{
Alteration of Cylindrospermopsin Content of Aphanizomenon ovalisporum (Cyanobacteria, Nostocales) due to Step-Down from Combined Nitrogen to Dinitrogen
}

\author{
Gábor Vasas ${ }^{1 *}$, Gyula Surányi ${ }^{1}$, István Bácsi², Márta M-Hamvas ${ }^{1}$, \\ Csaba Máthé ${ }^{1}$, Sándor Gonda ${ }^{1}$, George Borbely ${ }^{1}$ \\ ${ }^{1}$ Department of Botany, Faculty of Science, University of Debrecen, Debrecen, Hungary \\ ${ }^{2}$ Department of Hidrobiology, Faculty of Science, University of Debrecen, Debrecen, Hungary \\ Email: *vasas.gabor@science.unideb.hu
}

Received August 28, 2013; revised September 28, 2013; accepted October 5, 2013

Copyright (C) 2013 Gábor Vasas et al. This is an open access article distributed under the Creative Commons Attribution License, which permits unrestricted use, distribution, and reproduction in any medium, provided the original work is properly cited. In accordance of the Creative Commons Attribution License all Copyrights (C) 2013 are reserved for SCIRP and the owner of the intellectual property Gábor Vasas et al. All Copyright (C) 2013 are guarded by law and by SCIRP as a guardian.

\begin{abstract}
In this study we show that cylindrospermopsin (a cyanotoxin) content of filaments of Aphanizomenon ovalisporum ILC164 depended on growth on combined nitrogen or nitrogen fixation. Our results also demonstrated that the shift down of cyanobacterial filaments from combined nitrogen to dinitrogen fixing condition resulted in a significant decrease of cylindrospermopsin pool size which resumed a growth rate dependent manner as the heterocyst and nitrogenase formation appeared. The current study indicated that alteration of nitrogen metabolism of Aphanizomenon ovalisporum (Forti) induced changes in cyanotoxin (cylindrospermopsin) metabolism. In addition, this is the first report that isolated heterocysts, the differentiated anaerobic cells for nitrogen fixation of cyanobacteria, did not contain cylindrospermopsin.
\end{abstract}

Keywords: Cylindrospermopsin; Cyanobacteria; Heterocyst; Nitrogen Starvation; Nitrogenase; Cyanotoxin

\section{Introduction}

Cyanobacteria, free living obligate photoautotrophic microorganisms can drive energy from sunlight and carbon from carbon dioxide content of the air which dissolves in water. Some cyanobacteria are also able to fix atmospheric dinitrogen. Filamentous nitrogen fixing cyanobacteria that combine aerobic metabolism in their vegetative cells, with anaerobic metabolism in their differentiated cells, called heterocysts are widespread in many eutrophic ecosystems [1-7]. In addition, phytoplanktonic cyanobacteria are responsible for extensive blooms in natural surface waters. Bloom-forming cyanobacteria, among those the nitrogen fixing ones, have caused increasing concern over the last two decades in fresh water and marine environment, since a number of species are capable of producing metabolites that act as toxins of biological origin $[8,9,10]$. Harmful metabolites of cyanobacteria, called cyanotoxins are a diverse group of natu-

"Corresponding author. ral toxins both from the toxicological and chemical points of view. These toxins can be classified into several categories based on their mode of action. They are neurotoxins, hepatotoxins, harmful lipopolysaccharides, gastroenteral toxins and a variety of other, as yet unidentified toxic compounds [10-14]. In more recent years cylindrospermopsin $(\mathrm{CYN})$, a ulphur containing hepatotoxin (tricyclic guanidyl hydroxymethyluracil) known to produced by Cylindrospermopsis raciborskii was concerned in the worst known case of human poisoning in Australia $[12,15]$. Beside that CYN is produced by several other organisms as well, namely by Anabaena bergii, Aphanizomenon ovalisporum, A. flos-aquae, Raphidiopsis curvata, Umezakia natans [9,14-16].

The growth of cyanobacteria, like other organisms, is greatly affected by the concentration of nutrients of which there is often a short supply in natural environment [17]. These organisms are often subjected to limitation in phosphorous, combined nitrogen, sulphur etc. that may give rise to specific alteration of cyanobacterial phy- 
siology and metabolism. The response of obligate photoautotrophic cyanobacteria to changes in nutritional conditions is an active research topic [17,18]. However, there is still a need for studies about the interference of main nutrient limitation with cyanotoxin production of cyanobacteria, especially in the case of CYN. Recently, we have found that sulphate and phosphate starvation of A. ovalisporum, a nitrogen fixing and toxic, CYN producing cyanobacterium results in a characteristic reducetion of CYN pool size on the basis of cell number and dry mass of culture [19]. However, there are no data on the interference of combined nitrogen starvation with cyanotoxin content of $A$. ovalisporum. In addition, under combined nitrogen limitation, the nitrogen fixing filamentous cyanobacteria induce the differentiation of heterocysts, specialized cells for dinitrogen fixation [2-6,20]. Since nitrogen fixing cyanobacteria are frequently wellknown members of harmful blooms in natural waters, it deserves considerable attention to see the alteration of CYN content of cells shifted down from combined nitrogen growth condition to nitrogen fixing one. What is more, no cyanotoxin analysis, including CYN has been reported from heterocysts so far.

\section{Materials and Methods}

\subsection{Strain and Culture Conditions}

Cylindrospermopsin producing Aphanizomenon ovalisporum strain ILC-164 from Lake Kinneret, Israel was grown in liquid medium of Allen as described earlier [19]. The cultures were kept in glass flasks thermostatically maintained at $28^{\circ} \mathrm{C}$ and illuminated with cool white fluorescent light $\left(80 \mu \mathrm{mol} \cdot\right.$ photons $\left.\cdot \mathrm{m}^{-2} \cdot \mathrm{s}^{-1}\right)$. Aeration and mixing was achieved by bubbling with sterile air. Growth of the cultures was monitored by measurement of chlorophyll-a content $\left(\mathrm{Chl}-\mathrm{a} \mu \mathrm{g} \cdot \mathrm{ml}^{-1}\right)$ in $80 \%$ acetone extracts, cell number and dry mass content. Cell number and heterocyst frequency was determined in $5 \mu \mathrm{l}$ culture samples in triplicate (all cells of filaments were counted microscopically [19]. For dry mass measurement $3 \mathrm{ml}$ samples were centrifuged $(6.000 \times \mathrm{g}, 5 \mathrm{~min})$, washed and the pellets were lyophilized, weighted and cell mass $\left(\mathrm{mg} \cdot \mathrm{ml}^{-1}\right)$ calculated. All measurements were in triplicates [19].

\subsection{Nitrogen Starvation of A. ovalisporum Cultures}

Combined nitrogen grown exponential $A$. ovalisporum cultures were centrifuged $(6.000 \times \mathrm{g}$ for $10 \mathrm{~min}$, Beckman Avanti TM Centrifuge, J-25, at $25^{\circ} \mathrm{C}$ ) and the cell pellet was carefully washed twice with sterile combined nitrogen free medium. At zero time the washed cells were resuspended in sterile prewarmed full medium (control) at the same densities or in medium containing only $0.1 \mathrm{mM}$ of combined nitrogen $\left(\mathrm{NH}_{4} \mathrm{NO}_{3}\right)$ for shifting to dinitrogen fixation. The resuspended cultures were further cultivated under otherwise unchanged conditions. Samples were collected each day and used for assays as described above.

\subsection{Isolation of Heterocysts from Aphanizomenon ovalisporum}

Heterocysts were isolated by the lysozyme method of Fay [21,22]. Harvested filaments (centrifuged by $6.000 \times$ $\mathrm{g}$ for $5 \mathrm{~min}$ ) of a $10 \mathrm{l}$ culture fixing nitrogen for $336 \mathrm{~h}$ were washed free from culture medium and resuspended in $1 \mathrm{mM}$ Tris- $\mathrm{HCl}$ ( $\mathrm{pH} 7.6), 2 \mathrm{mM}$ EDTA, $0.5 \mathrm{M}$ mannitol. The filaments were maintained at $35^{\circ} \mathrm{C}$ and lysozyme (Sigma) was added at a concentration of $1.0 \mathrm{mg} \cdot \mathrm{ml}^{-1}$ and incubated for $45 \mathrm{~min}$. The suspension was put on ice and drawn through a Pasteur pipette. Then suspension was diluted 20-fold with mannitol-Tris buffer (without lysozyme and EDTA) and vigorously vortexed. Heterocysts were collected by differential centrifugation until no vegetative cells were apparent in the pellet (dry mass of vegetative cell free, isolated heterocysts was $127 \mathrm{mg}$ from a 101 culture).

\subsection{Western Blot Analysis}

For detection of dinitrogenase reductase protein in nitrogenase complex of cyanobacterial samples, proteins of cell free extracts of A. ovalisporum filaments (grown in presence or absence of combined nitrogen) were separated by $7.5 \%$ SDS polyacrylamide gel-electrophoresis and the gels were stained with Coomassie Brilliant Blue [23]. The molecular mass of sample proteins was calibrated with the help of SDS-PAGE markers (Pharmacia, LMW Kit). Western blots were carried out after SDS-PAGE to detect presence of dinitrogenase reductase in samples by a modified method of [24]. Briefly, the separated proteins (unstained gels) were transferred to nitrocellulose filter (Protran BA85, Schleicher and Schuell, Germany). Following protein transfer to nitrocellulose (300 mA, 3 hours, Tris-Glycine-Methanol) the membranes were incubated in blocking buffer (phosphate buffered saline /PBS/, pH 7.4 containing 2\% bovine serum albumin and $0.1 \%$ Tween $20 ; 1$ hour, room temperature). The blot was immunologically probed with a specific antibody raised to dinitrogenase reductase subunit (Chicken anti nifH, Agrisera AB, Sweden). Primary antibody was incubated with the membrane for 7 hours, at room temperature (the primary antibody was diluted 1:3000 in blocking buffer). A blotting grade secondary antibody enzyme conjugate (anti Chicken IgG Alkaline Phosphatase conjugate, Sigma) diluted 1:7000 in blocking buffer was added to bind to the primary antibody ( 2 hours, room temperature). The alkaline phosphatase 
catalyzed the formation of a stable and detectable purple product at the site of dinitrogenase reductase-anti nifH complex from the soluble substrate system 5-bromo-4chloro-3-indolyl-phosphate (BCIP, Sigma) and nitroblue tetrazolium (NBT, Sigma). The working buffer for BCIP-NBT substrate solution was $0.1 \mathrm{M}$ Tris- $\mathrm{HCl}(\mathrm{pH} 9.5)$ containing $0.5 \mathrm{mM} \mathrm{MgCl}$. After antibody incubations (primary and secondary antibodies) the membranes were washed 3 times in PBS containing 0.1\% Tween 20.

\subsection{Amplification of PS Gene and PKS Gene in Vegetative Cells and Heterocysts of A. ovalisporum}

DNA extraction was achieved by the phenol-chloroform method of $[25,26]$. PCR was used to analyse the presence or absence of the PKS and PS specific gene region, which are important parts of the gene cluster responsible for CYN biosynthesis. The photo preparation and the analysis of results was achieved using Cleaver Geldoc system. For the PS and PKS gene amplification, the PCR reaction was performed in $25 \mu$ l containing 12.5 master mix (Fermentas; PCR buffer, $0.05 \mathrm{u} / \mu \mathrm{l}$ taq Polimerase, 4 $\mathrm{mM} \mathrm{MgCl}_{2}, 0.4 \mathrm{nM} \mathrm{dntP}$ ), forward and reverse primer, DNA template (100 ng). Amplification was performed in a $\mathrm{T}$ Gradient thermocycler, consisting of an initial denaturation step at $95^{\circ} \mathrm{C}$ for $5 \mathrm{~min}$, followed by 35 cycles of $0.5 \mathrm{~min}$ at $94^{\circ} \mathrm{C}, 0.5 \mathrm{~min}$ at $5^{\circ} \mathrm{C}$ and $2 \mathrm{~min}$ at $72^{\circ} \mathrm{C}$ and a final extension step of $7 \mathrm{~min}$ at $72^{\circ} \mathrm{C}$. For the PKS gene amplification, the PCR reaction was performed as above, using PKS M4

(5'-GAAGCTCTGGAATCCGGTAA-3') and PKS M5 (5-AATCCTTACGGGATCCGGTGC-3) primers. For the PS gene amplification, the PCR reaction was performed as above, using PS M13

(5'-GAAGCTCTGGAATCCGGTAA-3') and Ps M14 (5-AATCCTTACGGGATCCGGTGC-3) primers [26]. The PCR products were electrophoresed in $1 \%$ agarose gel.

\subsection{Analysis of CYN Content of Combined Nitrogen Grown and Nitrogen Fixing Cells and Heterocysts of $A$. ovalisporum}

$3 \mathrm{ml}$ culture samples were centrifuged ( $6.000 \mathrm{~g}$ for $3 \mathrm{~min}$ ) and the pellets were lyophilized and used for CYN assay $[27,28]$. For CYN content assay of heterocysts, isolated heterocysts were resuspended in $1 \mathrm{mM}$ Tris- $\mathrm{HCl} \mathrm{pH} 7.6$ buffer and sonicated for $2 \mathrm{~min}$ in $15 \mathrm{~s}$ intervals on ice at full power. An aliquot of the sonicated material was lyophilized for dry mass assay. The rest of sonicated extract was centrifuged $\left(10.000 \mathrm{~g}, 30 \mathrm{~min}, 4^{\circ} \mathrm{C}\right)$ and the supernatant assayed for $\mathrm{CYN}$ content and a part of it saved for Western blotting. The cyanotoxin content was determined with the help of a slightly modified method of capillary electrophoresis as described earlier by our laboratory
[27,28]. A longer capillary $(85 \mathrm{~cm})$ was used to obtain better separation of the compounds. The data were normalized to the zero time control which was chosen to 100 $\%$ on basis of cell number.

\section{Results}

\subsection{Growth and Heterocyst Development of Aphanizomenon ovalisporum Cultures}

Growth curves (cell number $\cdot \mathrm{ml}^{-1}$ ) from representative experiments of combined nitrogen starved A. ovalisporum cultures are shown in Figure 1. It is obvious, the

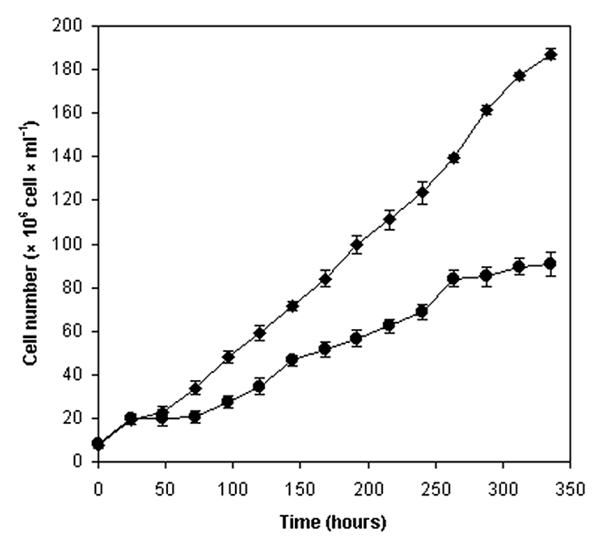

$\mathbf{A}$
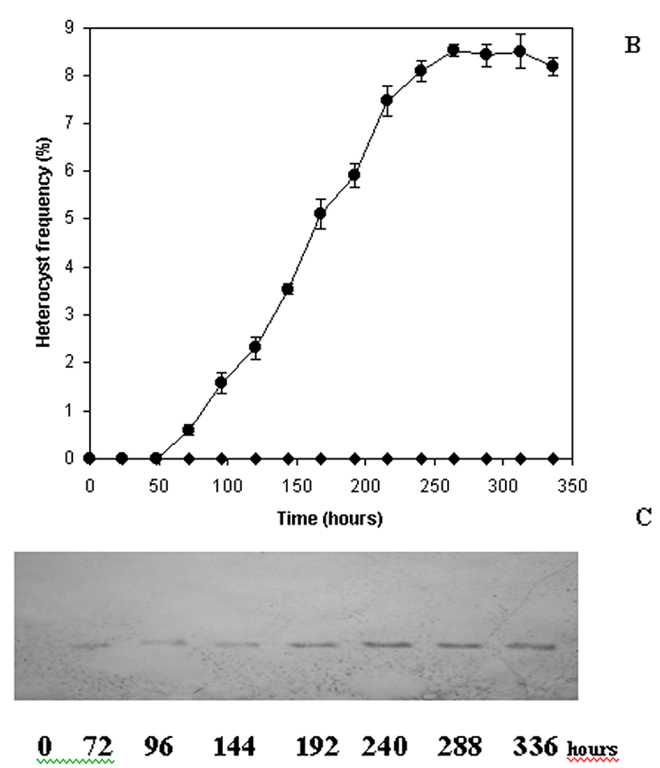

Figure 1. Growth of Aphanizomenon ovalisporum cultures on combined nitrogen step-down. An exponential phase culture grown on Allen medium was centrifuged, gently washed with combined nitrogen free medium and divided into two parts (zero time) and further cultivated in full medium (control - -) or starved for combined nitrogen (-๑-) throughout the experiment as described in Materials and Methods (A). Alterations of heterocyst frequency (B) and nitrogenase (C) Western blot of Aphanizomenon ovalisporum under control (combined nitrogen $-\bullet$ ) and nitrogen starvation (-•-) conditions. 
combined nitrogen starvation, the turn on dinitrogen fixation reduced the growth rate of the culture (Figure 1(A)). When heterocyst development was initiated by replacing combined nitrogen containing medium with minimal medium, growth ceased after 25 hours and recommenced $75 \mathrm{~h}$ later. Under the experimental condition described, the removal of combined nitrogen from a culture of A. ovalisporum caused the differentiation of a proportion of vegetative cells and resulted in the formation of heterocysts. The mature heterocyst frequency reached a maximum $(8.5 \%)$ at $250 \mathrm{~h}$ (Figure 1(B)) and was concomitant with the dinitrogenase reductase subunit level. Consequently, nitrogenase activity developed parallel with the heterocyst formation as shown by western blots (Figure 1(C)). The presence of heterocysts and dinitrogenase reductase first became detectable after 60 and 72 hours, respectively (Figures 1(B) and (C)). The heterocyst count and the amount of dinitrogenase reducetase then rose rapidly and the maximum nitrogenase level recorded $240 \mathrm{~h}$ after combined nitrogen starvation (Figure 1(B) and (C)).

\subsection{Occurrence of Dinitrogen-Reductase Protein in Aphanizomenon ovalisporum Cultures}

Protein extracts of culture samples (combined nitrogen grown and nitrogen fixing ones) and isolated heterocysts were subjected to SDS-polyacrylamide gel electrophoresis and Western blotted. The blots proved the presence of nitrogenase complex in heterocysts (Figures 1(C) and 2) which was not detectable in extracts of combined nitrogen grown vegetative cells (Figures 1(C) and 2). Increased amount of cell extracts of heterocysts loaded to polyacrylamide gel and transferred to nitrocellulose paper provided a linear signal increase for nitrogenase (Figure 2).

\subsection{Alteration of Cylindrospermopsin Content of Combined Nitrogen and Nitrogen Fixing Aphanizomenon ovalisporum Cultures}

We analyzed the alterations in cylindrospermopsin content of control and combined nitrogen starved (nitrogen fixing) cultures and isolated heterocysts with the help of capillary electrophoresis. When combined nitrogen grown A. ovalisporum cells were transferred from nitrogen efficient medium to dinitrogen, concomitant with the differentiation events the CYN content of the cells was decreased to a minimum value at $150 \mathrm{~h}$ (Figure 3). After this period of time the CYN content of cultures increased to about $95 \%$ of control level (Figure 3). In control, combined nitrogen grown cultures the CYN content of $A$. ovalisporum cells was stable and the amount of CYN did not change on cell number base throughout the experiment (Figure 3). It is worth to mention that in nitrogen fixing cultures CYN content of cells started to rise $(150 \mathrm{~h})$ when the increase of nitrogenase level was detected concomitantly (Figures 1(C) and 3).

\subsection{Amplification of PS Gene and PKS Gene in Vegetative Cells and Heterocysts of A. ovalisporum}

The vegetative cells (as positive control) and heterocysts of the strains of A. ovalisporum, a well-known CYN producing strain (ILC-164) were tested for PKS and PS genes to investigate whether the gene rearrangement affects the detection of genes responsible for CYN biosynthesis. The amplified genes were detected in the vegetative cells and heterocysts too as shown on Figure 4.

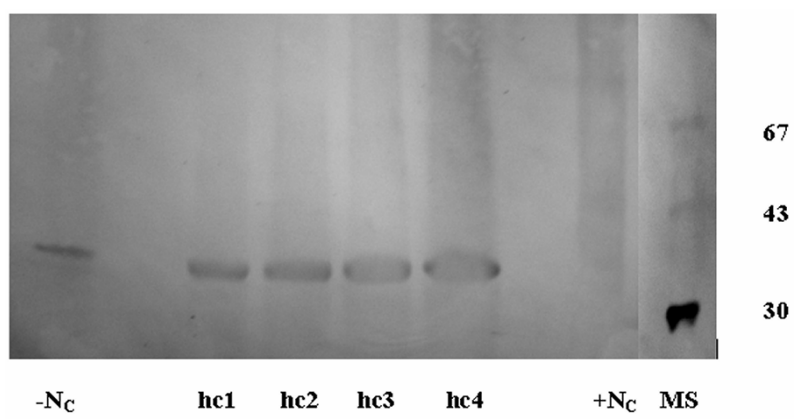

Figure 2. Presence of dinitrogenase reductase subunits in vegetative cells and heterocysts. Extracts of nitrogen fixing $\left(-\mathrm{N}_{c}, 25 \mu \mathrm{g}\right.$ protein) filaments and isolated heterocysts in increasing amount [hc1 (25 $\mu \mathrm{g})$; hc2 (50 $\mu \mathrm{g})$; hc3 (75 $\mu \mathrm{g})$, hc4 $(100 \mu \mathrm{g}$ protein)] and combined nitrogen grown filaments $\left(+N_{c}, 25 \mu\right.$ protein) were blotted and are shown by one representative experiment.

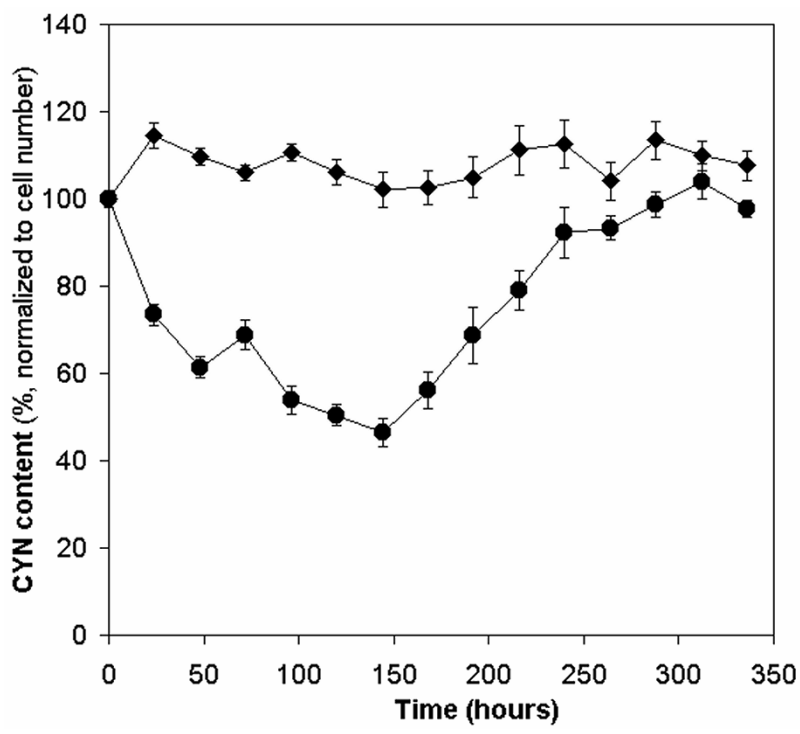

Figure 3. Alteration of cylindrospermopsin content of control $(-\bullet)$ and nitrogen fixing $(-\bullet-)$ cultures. In time 0 sample, the basal level of cylindrospermopsin was $1.91 \times$ $10^{-4} \mathrm{ng}$ per cell. 


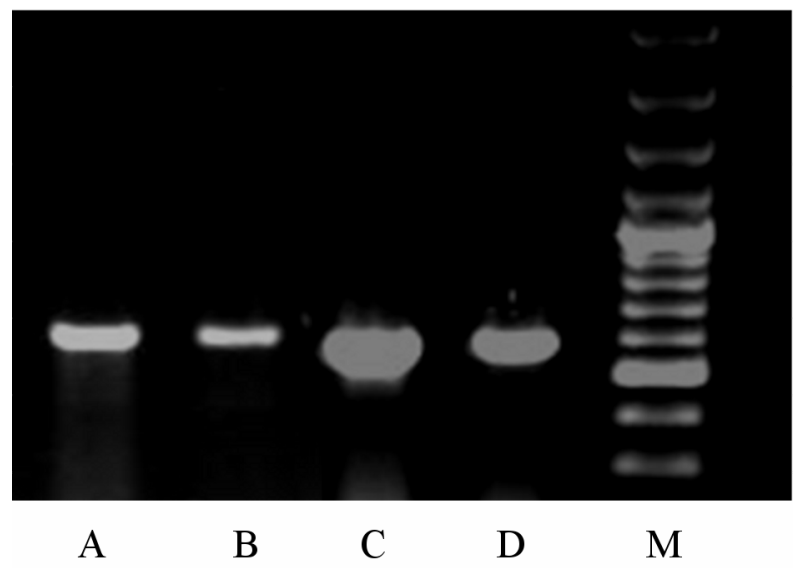

Figure 4. Presence of PKS and PS genes in vegetative cells and heterocyst. PKS in combined nitrogen grown filaments (A) and isolated heterocysts (B); PS in extracts of combined nitrogen grown (C) and isolated heterocysts (D); marker (M).

\subsection{Cylindrospermopsin Content of Heterocysts}

In order to ascertain whether the isolated heterocysts contain CYN, heterocysts of 101 culture of A. ovalisporum (127 mg dry mass) were isolated and after cyanotoxin extraction the extracts were assayed for CYN by capillary electrophoresis (Figure 5). Figure 5(A) presents the capillary electrophoretic separation of compounds of isolated heterocysts and no CYN was detected. To show the unequivocal identity of CYN peak in the electropherogram the capillary electrophoretic run was spiked with HPLC-purified CYN standard (insert of Figure 5(A)). CYN was purified as our laboratory described earlier [27] and its electropherogram is shown on Figure 5(C). In contrast to the isolated heterocysts, the cyanotoxin extracts of combined nitrogen grown cells contained CYN (Figure 5(B)).

\section{Discussion}

Filamentous cyanobacteria grown in presence of a source of assimilable combined nitrogen consist of undifferentiated vegetative cells. Following transfer to medium free of nitrogen source, many species, among those Aphanizomenon ovalisporum develop specialized cells known as heterocysts at regular intervals in each filament. Combined nitrogen depletion results in striking changes in the morphology, ultra structure, pigment composition, photosynthesis, nitrogen fixing activity, DNA structure etc. of nitrogen fixing cyanobacteria [1-6,20]. The heterocysts are sites of anaerobic nitrogen fixation and they are formed concomitantly with combined nitrogen depletion. The molecular basis of those processes is well studied and understood $[2,3,5,6,29]$.

Toxic bloom developments of cyanobacteria caused mainly by eutrophication of surface water bodies, both in

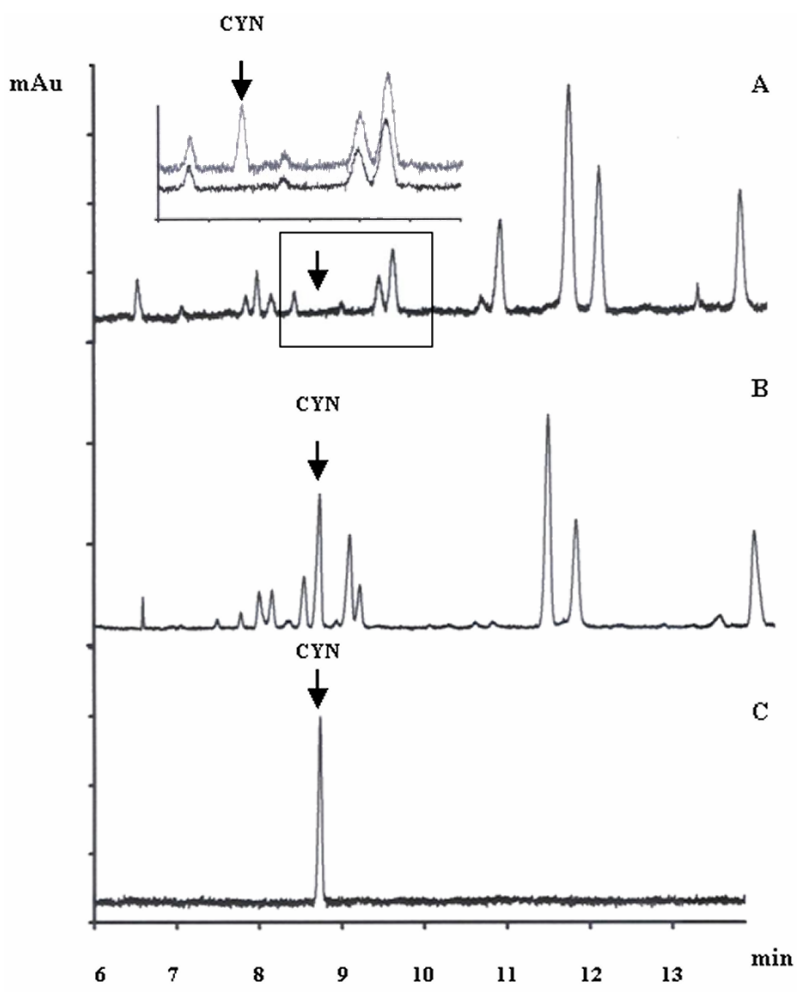

Figure 5. Capillary electrophoretic separation of CYN from heterocysts of Aphanizomenon ovalisporum. Insert in (A) shows a representative experiment which was spiked with 5 $\mu \mathrm{g} \cdot \mathrm{ml}^{-1} \mathrm{CYN}$. CYN content of the combined nitrogen grown culture (B). Electropherogram of HPLC-purified CYN standard $\left(10 \mu \mathrm{g} \cdot \mathrm{ml}^{-1}\right)$.

marine and fresh waters are a worldwide problem. In addition toxic cyanobacterial blooms imply a high risk for human and animal health due to the ability of several species to produce potent toxins [7]. Cylindrospermopsin, a water soluble cyanotoxin is described as a potent heptotoxin with additional affection of kidneys, heart, thymus, spleen and intestine [8,12-14,30]. It is believed that the damage is chiefly caused by inhibition of protein synthesis [31-34]. What is more, carcinogenic and allergic activities were suggested recently due to the presence of uracil and sulphinated guanidino moieties [35-37]. In addition, [27] demonstrated that CYN interferes with plant metabolism as well. The biosynthesis of CYN is understood [26] and its chemical structure and feeding experiments with stable isotopes suggested the role of polyketide synthase [38]. [39] recommended that cyanobacterial amidinotransferases are likely to be involved in the formation of guanidino-acetic acid, a precursor of CYN.

Nutrient limitation stress and its regulation in cyanobacteria may have much common with heterotrophic bacterial nutrient restriction [40]. Therefore, one would anticipate the influence of nitrogen starvation on the metabolism of cyanotoxins, herein on CYN. It has been long 
known, the combined nitrogen starvation results in a transient stop of growth of cyanobacteria capable for nitrogen fixation. Later, as consequence of alteration of gene expression, formation of heterocysts and nitrogenase, the growth resumes, though not necessarily at the same rate $[6,25]$. In this respect $A$. ovalisporum behaved as it was suspected under nitrogen shift down (Figure 1). Nevertheless, no data are available how nitrogen starvetion alters the cyanotoxin content of CYN producing and nitrogen fixing $A$. ovalisporum cells. In addition, spatial and temporal variation of cyanotoxin content and toxicity of bloom samples is well documented [11,15,41-43]. In previous studies of microcystin production of organisms that do not fix nitrogen (e.g. Microcystis aeruginosa) it became clear that nitrate deprivation alters the cyanotoxin production. [42] demonstrated conclusively that microcystin content of cells and cell division is tightly coupled in nitrogen limited cultures. In the case of desmetyl-3-micro-cystin-RR producing Oscillatoria agardhii (not $\mathrm{N}_{2}$ fixing cyanobacterium) high toxin production correlated with high combined nitrogen concentration in the culturing medium [44]. Basically similar data were obtained for microcystin producing Anabaena strains, but under nitrate grown conditions only [45]. Our finding suggest for a nitrogen fixing organism (A. ovalisporum) that the cyanotoxin content (CYN) of cells is dependent on metabolic activity of cells which most of the cases was correlated with growth rate (Figures $\mathbf{1}$ and $\mathbf{3}$ ). However, when nitrogen limitation started the CYN content of cells dramatically decreased and resumed only after an efficient nitrogenase functioning which supported the increase of growth rate of nitrogen fixing cells. In addition, our former study undoubtedly proved for the same organism (A. ovalisporum) that sulphur and phosphorus limitation changed $\mathrm{CYN}$, a sulphur containing cyanotoxin production of cells in a similar manner [19].

It is known that isolated heterocysts are highly active in light driven nitrogen fixation measured by acetylene reduction and in protein synthesis [46-48]. Although the heterocysts contained the PKS-PS genes necessary for CYN biosynthesis (Figures 3 and 4), the isolated heterocysts of A. ovalisporum did not contain CYN as shown by capillary electrophoresis (Figure 5). The breakdown of reserve molecules during heterocyst formation and dramatic alteration of gene expression in heterocysts has been noted long ago $[2,3,5,6,16,20,25,49,50]$. The current study indicates that the CYN content of isolated heterocysts was reduced in A. ovalisporum_under combined nitrogen starvation. This is not surprising, since it is well known that during heterocyst differenttiation no net increase in cell mass of filament is possible and it is concomitant with basic alteration of heterocyst and vegetative cell metabolism [25]. Taking into account that the heterocyst focuses on nitrogen fixation under intra- cellu-lar anaerobic conditions, it may be that in such circumstances, the toxin production is blocked. We suggest that these metabolic changes might be the reason of the disappearance of CYN during heterocyst differentiation.

\section{Conclusion}

Our findings suggest for the nitrogen fixing A. ovalisporum that the CYN content of cells is dependent on metabolic activity of cells, which is correlated with growth rate. CYN content of cells dramatically decreased when nitrogen limitation started and resumed only after an efficient nitrogenase functioning, which supported the increase of growth rate. The current study indicates that the CYN content of isolated heterocysts was reduced in $A$. ovalisporum, although the PKS and PS genes responsible for CYN biosinthesis were present in differentiated heterocysts.

\section{Acknowledgements}

This work has been supported by Hungarian National Research Foundation Grants OTKA K81370, F046493, GVOP-3.2.1.-2004-04-0110/3.0 and GVOP-TST 3.3.1-05/ 1-2005-05-0004/3.0 which is greatly acknowledged. The Bolyai J. research support for G. Vasas is acknowledged. All authors declare that they share no conflicts of interest.

\section{REFERENCES}

[1] C. P. Wolk, "Heterocysts," In: N. G. Carr and B. A. Whitton, Eds., The Biology of Cyanobacteria, University of California Press, 1982, pp. 359-386.

[2] W. J. Buikema and R. Haselkorn, "Molecular Genetics of Cyanobacterial Development," Annual Review of Plant Physiology and Plant Molecular Biology, Vol. 44, 1993, pp. 33-52. http://dx.doi.org/10.1146/annurev.pp.44.060193.000341

[3] C. P. Wolk, A. Ernst and J. Elhai, "Heterocyst Metabolism and Development," In: D. A. Bryant, Ed., The Molecular Biology of Cyanobacteria. Dordrecht, Kluwer Academic Publishers, The Netherlands, 1994. pp. 769-823. http://dx.doi.org/10.1007/978-94-011-0227-8 27

[4] H. Böhme, "Regulation of Nitrogen Fixation in Heterocyst-Forming Cyanobacteria," Trends in Plant Science, Vol. 3, 1998, pp. 346-351. http://dx.doi.org/10.1016/S1360-1385(98)01290-4

[5] D. G. Adams and P. S. Duggan, "Tansley Review No. 107. Heterocyst and Akinete Differentiation in Cyanobacteria," New Phytologist, Vol. 144, 1999, pp. 3-33. http://dx.doi.org/10.1046/j.1469-8137.1999.00505.x

[6] A. Herrero, A. M. Muro-Pastor, A. Valladares and E. Flores, "Cellular Differentiation and the NtcA Transcription Factor in Filamentous Cyanobacteria," FEMS Microbiology Reviews, Vol. 28, 2004, pp. 469-487. http://dx.doi.org/10.1016/j.femsre.2004.04.003 
[7] L. R. Oliver and G. G. Ganf, "Freshwater Blooms," In: B. A. Whitton, and M. Potts, Eds., The Ecology of Cyanobacteria-Their Diversity in Time and Space, Kluwer Academic, Dordrecht, The Netherlands, 2000, pp. 149194.

[8] I. R. Falconer, "Algal Toxins in Seafood and Drinking Water," Academic Press, Waltham, 1993.

[9] I. Chorus and J. Bartram, Eds., "Toxic Cyanobacteria in Water: A Guide to Their Public Health Consequences, Monitoring and Management," CRC Press, Boca Raton, 1999. http://dx.doi.org/10.4324/9780203478073

[10] C. S. Dow and U. K. Swoboda, "Cyanotoxins," In: B. A. Whitton and M. Potts, Eds., The Ecology of Cyanobacteria, Kluwer Academic Publishers, The Netherlands, 2002, pp. 613-632..

http://dx.doi.org/10.1007/0-306-46855-7_22

[11] G. A. Codd and G. K. Poon, "Cyanobacterial Toxins," In: L. J. Rogers and J. R. Gallon, Eds., Biochemistry of the Algae and Cyanobacteria, Oxford University Press, Oxford, 1989.

[12] P. R. Hawkins, M. T. Runnegar, A. R. Jackson and I. R. Falconer, "Severe Hepatotoxicity Caused by the Tropical Cyanobacterium (Blue-Green Alga) Cylindrospermopsis raciborskii (Woloszynska) Seenaya and Subba Raju Isolated from a Domestic water Supply Reservoir," Applied Environmental Microbiology, Vol. 50, 1985, pp. 1292-1295.

[13] W. W. Carmichael, "Cyanobacteria Secondary Metabolites-The Cyanotoxins," Journal of Applied Microbiology, Vol. 72, 2008, pp. 445-459.

[14] S. G. Bell and G. A. Codd, "Cyanobacterial Toxins and Human Health," Reviews in Medical Microbiology, Vol. 5, 1994, pp. 256-264. http://dx.doi.org/10.1097/00013542-199410000-00005

[15] M. L. Saker and D. J. Griffiths, "The Effect of Temperature on Growth and Cylindrospermopsin Content of Seven Isolates of Cylindrospermopsis raciborskii (Nostocales, Cyanophyceae) from Water Bodies in Northern Australia," Phycologia, Vol. 39, 2000, pp. 349-354. http://dx.doi.org/10.2216/i0031-8884-39-4-349.1

[16] R. Banker, S. Carmeli, O. Hadas, B. Teltsch, et al., "Identification of Cylindrospermopsin in Aphanizomenon ovalisporum (Cyanophyceae) Isolated from Lake Kinneret, Israel 1," Journal of Phycology, Vol. 33, 1997, pp. 613-616. http://dx.doi.org/10.1111/j.0022-3646.1997.00613.x

[17] N. Tandeau de Marsac and J. Houmard, "Adaptation of Cyanobacteria to Environmental Stimuli: New Steps towards Molecular Mechanisms," FEMS Microbiology Letters, Vol. 104, 1993, pp. 119-189.

http://dx.doi.org/10.1111/j.1574-6968.1993.tb05866.x

[18] A. Herrero and E. Flores, Eds., "The Cyanobacteria: Molecular Biology, Genomics and Evolution," Caister Academic Press, Norfolk, 2008.

[19] I. Bácsi, G. Vasas, G. Surányi, M. M-Hamvas, et al., "Alteration of Cylindrospermopsin Production in Sulfateor Phosphate-Starved Cyanobacterium Aphanizomenon ovalisporum," FEMS Microbiology Letters, Vol. 259, 2006, pp. 303-310. http://dx.doi.org/10.1111/j.1574-6968.2006.00282.x

[20] D. G. Adams, "Heterocyst Formation in Cyanobacteria," Current Opinion in Microbiology, Vol. 3, 2000, pp. 618624. http://dx.doi.org/10.1016/S1369-5274(00)00150-8

[21] P. Fay, "Heterocyst isolation," Methods in Enzymology, Vol. 69, 1980, pp. 801-812.

[22] J. Udvardy, G. Borbely, A. Juhász and G. L. Farkas, "Thioredoxins and the Redox Modulation of Glucose-6-Phosphate Dehydrogenase in Anabaena sp. Strain PCC 7120 Vegetative Cells and Heterocysts," Journal of Bacteriology, Vol. 157, 1984, pp. 681-683.

[23] U. K. Laemmli, "Cleavage of Structural Proteins during the Assembly of the Head of Bacteriophage T4," Nature, Vol. 227, 1970, pp. 680-685. http://dx.doi.org/10.1038/227680a0

[24] H. Towbin and J. Gordon, "Immunoblotting and Dot Immunobinding: Current Status and Outlook," Journal of Immunological Methods, Vol. 72, 1984, pp. 313-340. http://dx.doi.org/10.1016/0022-1759(84)90001-2

[25] S. Bradley and N. G. Carr, "Heterocyst Development in Anabaena cylindrica: The Necessity for Light as an Initial Trigger and Sequential Stages of Commitment," Journal of General Microbiology, Vol. 101, 1977, pp. 291-297. http://dx.doi.org/10.1099/00221287-101-2-291

[26] J. Muenchhoff, K.S. Siddiqui, A. Poljak, M.J. Raftery, et al., "A Novel Prokaryotic 1-Arginine: Glycine Amidinotransferase Is Involved in Cylindrospermopsin Biosynthesis," FEBS Journal, Vol. 277, 2010, pp. 3844-3860. http://dx.doi.org/10.1111/j.1742-4658.2010.07788.x

[27] G. Vasas, A. Gáspár, G. Surányi, G. Batta, et al., “Capillary Electrophoretic Assay and Purification of Cylindrospermopsin, a Cyanobacterial Toxin from Aphanizomenon ovalisporum, by Plant Test (Blue-Green Sinapis Test)," Analytical Biochemistry, Vol. 302, 2002, pp. 95-103. http://dx.doi.org/10.1006/abio.2001.5525

[28] G. Vasas, A. Gaspar, C. Pager, G. Suranyi, et al., "Analysis of Cyanobacterial Toxins (Anatoxin-A, Cylindrospermopsin, Microcystin-LR) by Capillary Electrophoresis," Electrophoresis, Vol. 25, 2004, pp.108-115. http://dx.doi.org/10.1002/elps.200305641

[29] X. Xu, J. Elhai and C. P. Wolk, "Transcriptional and Developmental Responses by Anabaena to Deprivation of Fixed Nitrogen," In: A. Herrero and E. Flores, Eds., The Cyanobacteria: Molecular Biology, Genomics and Evolution, Caister Academic Press, Norfolk, 2008, pp. 383-422.

[30] P. R. Hawkins, N. R. Chandrasena, G. J. Jones, A. R. Humpage and I. R. Falconer, "Isolation and Toxicity of Cylindrospermopsis raciborskii from an Ornamental Lake," Toxicon, Vol. 35, 1997, pp. 341-346. http://dx.doi.org/10.1016/S0041-0101(96)00185-7

[31] S. M. Froscio, A. R. Humpage, P. C. Burcham and I. R. Falconer, "Cell-Free Protein Synthesis Inhibition Assay for the Cyanobacterial Toxin Cylindrospermopsin," Environmental Toxicology, Vol. 16, 2001, pp. 408-412. http://dx.doi.org/10.1002/tox.1050

[32] E. Valério, P. Pereira, M. L. Saker, S. Franca and R. Tenreiro, "Molecular Characterization of Cylindrospermopsis raciborskii Strains Isolated from Portuguese Fre- 
shwaters," Harmful Algae, Vol. 4, 2005, pp. 1044-1052. http://dx.doi.org/10.1016/j.hal.2005.03.002

[33] J. S. Metcalf, A. Barakate and G. A. Codd, "Inhibition of Plant Protein Synthesis by the Cyanobacterial Hepato toxin, Cylindrospermopsin," FEMS Microbiology Letters, Vol. 235, 2004, pp. 125-129. http://dx.doi.org/10.1111/j.1574-6968.2004.tb09576.x

[34] S. M. Froscio, A. R. Humpage, W. Wickramasinghe, G. Shaw and I .R. Falconer, "Interaction of the Cyanobacterial Toxin Cylindrospermopsin with the Eukaryotic Protein Synthesis System," Toxicon, Vol. 51, 2008, pp.191198. http://dx.doi.org/10.1016/j.toxicon.2007.09.001

[35] A. R. Humpage, M. Fenech, P. Thomas and I. R. Falconer, "Micronucleus Induction and Chromosome Loss in Transformed Human White Cells Indicate Clastogenic and Aneugenic Action of the Cyanobacterial Toxin, Cylindrospermopsin," Mutation Research, Vol. 472, 2000, pp. 155161. http://dx.doi.org/10.1016/S1383-5718(00)00144-3

[36] P. J. Murphy and C. W. Thomas, "The Synthesis and Biological Activity of the Marine Metabolite Cylindrospermopsin," Chemical Society Reviews, Vol. 30, No. 5, 2001, pp. 303-312. http://dx.doi.org/10.1039/b103435a

[37] A. Torokne, A. Palovics and M. Bankine, "Allergenic (Sensitization, Skin and Eye Irritation) Effects of Freshwater Cyanobacteria-Experimental Evidence," Environmental Toxicology, Vol. 16, No. 6, 2001, 512-516. http://dx.doi.org/10.1002/tox.10011

[38] D. L. Burgoyne, T. K. Hemscheidt, R. E. Moore and M. T. Runnegar, "Biosynthesis of Cylindrospermopsin," The Journal of Organic Chemistry, Vol. 65, No. 1, 2000, pp. 152-156. http://dx.doi.org/10.1021/j0991257m

[39] G. Shalev-Alon, A. Sukenik, O. Livnah, R. Schwarz and A. Kaplan, “A Novel Gene Encoding Amidinotransferase in the Cylindrospermopsin Producing Cyanobacterium Aphanizomenon ovalisporum," FEMS Microbiology Letters, Vol. 209, No. 1, 2002, pp. 87-91. http://dx.doi.org/10.1111/j.1574-6968.2002.tb11114.x

[40] F. Neidhardt, "Escherichia coli and Salmonella typhimurium," In: F. Neidhardt, J. Ingra- ham, K. Low, B. Magasanik, et al., Eds., "Escherichia coli and Salmonella typhimurium: Cellular and Molecular Bio- logy," Vol. 2, American Society for Microbiology, 1987, pp. 1313-1317.

[41] A. J. Van der Westhuizen and J. N. Eloff, "Effect of
Culture Age and $\mathrm{pH}$ of Culture Medium on the Growth and Toxicity of the Blue-green Alga Microcystis aeruginosa," Zeitschrift für Pflanzenphysiologie, Vol. 110, No. 2, 1983, pp. 157-163.

[42] P. T. Orr and G. J. Jones, "Relationship between Microcystin Production and Cell Division Rates in NitrogenLimited Microcystis aeruginosa Cultures," Limnology and Oceanography, Vol. 43, No. 7, 1998, pp. 1604-1614. http://dx.doi.org/10.4319/1o.1998.43.7.1604

[43] M. K. Rogalus and M. C. Watzin, "Evaluation of Sampling and Screening Techniques for Tiered Monitoring of Toxic Cyanobacteria in Lakes," Harmful Algae, Vol. 7, No. 4, 2008, pp. 504-514.

[44] K. Sivonen, "Effects of Light, Temperature, Nitrate, Orthophosphate, and Bacteria on Growth of and Hepatotoxin Production by Oscillatoria agardhii Strains," Applied and Environmental Microbiology, Vol. 56, No. 9, 1990, pp. 2658-2666.

[45] J. Rapala, K. Sivonen, C. Lyra and S. I. Niemelä, "Variation of Microcystins, Cyanobacterial Hepatotoxins, in Anabaena spp. as a Function of Growth Stimuli," Applied Environmental Microbiology, Vol. 63, No. 6, 1997, pp. 2206-2212.

[46] H. Fleming and R. Haselkorn, "Differentiation in Nostoc muscorum: Nitrogenase Is Synthesized in Heterocysts," Proceedings of the National Academy of Sciencesof the United States of America, Vol. 70, No. 10, 1973, pp. 2727 2731. http://dx.doi.org/10.1073/pnas.70.10.2727

[47] H. Fleming and R. Haselkorn, "The Program of Protein Synthesis during Heterocyst Differentiation in NitrogenFixing Blue-Green Algae," Cell, Vol. 3, No. 2, 1974, 159170. http://dx.doi.org/10.1016/0092-8674(74)90121-4

[48] S. Janaki and C. P. Wolk, "Synthesis of Nitrogenase by Isolated Heterocysts," Biochimica et Biophysica Acta, Vol. 696, No. 2, 1982, pp. 187-192.

[49] E. Talpasayi and K. Kale, "Induction of Heterocysts in the Blue-Green Alga Anabaena Ambigua," Current Science, Vol. 36, 1967, pp. 218-219.

[50] S. A. Kulasooriya, N. J. Lang and P. Fay, "The Heterocysts of Blue-Green Algae. III. Differentiation and Nitrogenase Activity," Proceedings of the Royal Society of London, Series B, Vol. 181, No. 1063, 1972, pp. 199209. http://dx.doi.org/10.1098/rspb.1972.0046

\section{List of Abbreviations}

CYN: cylindrospermopsin 